\title{
PENGARUH PEMBERIAN JUS BIJI PEPAYA (CARICA PAPAYA L.) TERHADAP RASIO KOLESTEROL LDL:HDL TIKUS SPRAGUE DAWLEY DISLIPIDEMIA
}

\author{
Dyah Agustina, Hesti Murwani R \\ Program Studi Ilmu Gizi Fakultas Kedokteran Universitas Diponegoro \\ Jl.Dr.Sutomo No.14, Semarang, Telp (024) 8453708, Email : gizifk@undip.ac.id
}

\begin{abstract}
Background : Dyslipidemia as a major risk factor for cardiovascular disease was a condition characterized by increasing concentrations of total cholesterol, $L D L$ cholesterol $(L D L-C)$, and triglycerides and also decreased $H D L$ cholesterol (HDL-C) concentrations than normal range. The most accurate tool to predict cardiovascular disease was comparison of LDL cholesterol and HDL cholesterol is called the LDL-C to HDL-C ratio. Dyslipidemia controlled can be done through diet modification, for instance increasing hypolipidemic food consumption. Papaya seeds were seeds that has hipolipidemia and antioxidant effects through the phytochemicals substances involved flavonoids, saponins and tannins.

Objective : To analyze the effect of papaya seed juice to the $L D L-C$ to $H D L-C$ ratio of dyslipidemia Sprague Dawley rats.

Method: This research was true-experimental laboratory using pre and post test with randomized control group design. Samples were 28 male Sprague Dawley rats, aged 8 weeks old and weight 150-180 gram, induced dyslipidemia, given papaya seed juice at $400 \mathrm{mg}$ and $800 \mathrm{mg}$ dosages for 30 days. The LDL-C to HDL-C ratio was obtained from LDL to HDL cholesterol which is LDL cholesterol and HDL cholesterol were measured by diasis reagents and CHOD-PAP method. Normality of data were tested by Shapiro Wilks. Data were analyze by Paired $t$ test, One Way Anova and LSD.

Result : The administration of papaya seed juice that contain 646,1 $\mathrm{mg}$ flavonoid, 69,3 $\mathrm{mg}$ saponin, and 140,9 $\mathrm{mg}$ tannin/100 gram at $400 \mathrm{mg}$ and $800 \mathrm{mg}$ dossages can decreased LDL-C to HDL-C ratio from 2,64 $\pm 0,70$ to

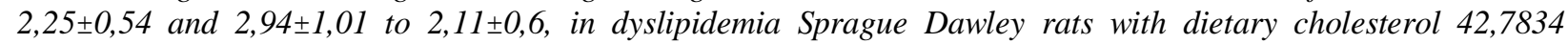
$m g / d a y$, but it was not significant $(p>0,05)$. There were no significant difference $(p>0,05)$ between all of groups.

Conclusion : Papaya seeds juice at $400 \mathrm{mg} / \mathrm{rat} /$ day and $800 \mathrm{mg} / \mathrm{rat} /$ day dossages for 30 days can decrease $\mathrm{LDL}-\mathrm{C}$ to HDL-C ratio of dyslipidemia Sprague Dawley rats but it is not significant. There aren't difference effectively between $400 \mathrm{mg}$ and $800 \mathrm{mg}$ dossages.
\end{abstract}

Key Words : Papaya Seed Juice, LDL to HDL Cholesterol Ratio, Dyslipidemia

\section{ABSTRAK}

Latar Belakang : Dislipidemia sebagai faktor risiko utama penyakit kardiovaskular merupakan suatu keadaan yang ditandai dengan peningkatan konsentrasi kolesterol total, kolesterol LDL (Low Density Lipoprotein), dan trigliserida serta penurunan konsentrasi kolesterol HDL (High Density Lipoprotein) dari batas normal. Parameter paling akurat dalam memprediksi penyakit tersebut adalah perbandingan nilai kolesterol LDL dan HDL yang disebut rasio kolesterol LDL:HDL. Pengendalian dislipidemia dapat dilakukan melalui modifikasi diet, salah satunya dengan meningkatkan konsumsi makanan sumber efek hipolipidemik. Biji pepaya merupakan biji yang memiliki efek hipolipidemia dan antioksidan melalui zat fitokimia yang dikandungnya meliputi flavonoid, saponin dan tannin.

Tujuan : Menganalisis pengaruh pemberian jus biji pepaya terhadap rasio kolesterol LDL:HDL tikus Sprague Dawley dislipidemia.

Metode : Jenis penelitian ini adalah true-experimental laboratorik dengan pre and post test with randomized control group design. Subjek penelitian yaitu 28 ekor tikus Sprague Dawley jantan berusia 8 minggu dengan berat 150-180 gram yang diinduksi dislipidemia, diberi jus biji pepaya dengan dosis $400 \mathrm{mg}$ dan $800 \mathrm{mg}$ per hari selama 30 hari. Rasio kolesterol LDL:HDL didapat dari perbandingan kadar kolesterol LDL dengan kolesterol HDL dimana kolesterol LDL dan kolesterol HDL ditentukan menggunakan reagen diasis dan metode CHOD-PAP. Normalitas data diuji dengan Shapiro Wilks. Data dianalisis menggunakan uji Paired t-test, One Way Anova dan LSD.

Hasil : Pemberian jus biji pepaya yang mengandung 646,1 mg flavonoid, 69,3 mg saponin, dan 140,9 mg tanin tiap 100 gram pada dosis $400 \mathrm{mg}$ dan $800 \mathrm{mg}$ mampu menurunkan rasio kolesterol LDL:HDL dari 2,64 $\pm 0,70$ menjadi 2,25 $\pm 0,54$ dan 2,94 $\pm 1,01$ menjadi 2,11 $\pm 0,65$ pada tikus Sprague Dawley dislipidemia dengan diet kolesterol $42,7834 \mathrm{mg} / \mathrm{hari}$, namun tidak bermakna ( $p>0,05)$. Tidak terdapat perbedaan bermakna $(p>0,05)$ antar kelompok.

${ }^{*}$ Penulis Penanggungjawab 
Simpulan : Jus biji pepaya pada dosis $400 \mathrm{mg} / \mathrm{ekor} / \mathrm{hari}$ dan $800 \mathrm{mg} / \mathrm{ekor} / \mathrm{hari}$ selama 30 hari mampu menurunkan rasio kolesterol LDL:HDL tikus Sprague Dawley dislipidemia, namun tidak bermakna. Tidak terdapat perbedaan efektivitas antara dosis $400 \mathrm{mg}$ dan $800 \mathrm{mg}$.

Kata Kunci : Biji Pepaya (Carica papaya L.), Rasio Kolesterol LDL:HDL, Dislipidemia

\section{PENDAHULUAN}

Penyakit kardiovaskular merupakan penyebab utama mortalitas dan morbiditas di dunia. Menurut data World Health Organization (WHO) tahun 2008, dari 57 juta kematian di dunia, diantaranya 17,3 juta orang meninggal karena penyakit kardiovaskular atau 30\% dari seluruh kematian di dunia. Lebih dari $80 \%$ kematian akibat penyakit kardiovaskular terjadi di negara berkembang. ${ }^{1}$ Indonesia merupakan salah satu negara berkembang dimana penyebab utama kematian berasal dari penyakit kardiovaskular yaitu 9,49\% dan $8,01 \%$ pada tahun 2009 dan $2010 .^{2}$ Faktor risiko utama penyakit kardiovaskular yaitu dislipidemia, suatu keadaan yang ditandai dengan peningkatan konsentrasi kolesterol total, kolesterol LDL, dan trigliserida serta penurunan konsentrasi kolesterol HDL dari batas normal. ${ }^{3}$ Parameter paling akurat dalam memprediksi penyakit kardiovaskular adalah perbandingan nilai kolesterol LDL dan HDL yang disebut rasio kolesterol LDL : HDL. ${ }^{4}$

Pengendalian dislipidemia sebagai faktor risiko utama penyakit kardiovaskular, salah satunya dapat dilakukan melalui modifikasi diet dengan membatasi asupan lemak jenuh dan kolesterol. ${ }^{5}$ Selain itu, juga dengan meningkatkan konsumsi makanan sumber efek hipolipidemia. Hal tersebut menjadi alternatif pengendalian dislipidemia yang lebih efektif dibandingkan upaya kuratif saja. Eksplorasi sumber hayati dengan efek hipolipidemia yang dianjurkan salah satunya adalah biji pepaya.

Pepaya merupakan tanaman yang banyak dibudidayakan di Indonesia. Hampir semua bagian dari tanaman pepaya memiliki khasiat untuk tubuh, akan tetapi pada umumnya masyarakat hanya mengonsumsi buahnya, sedangkan bijinya dibuang. Padahal biji tersebut memiliki efek hipolipidemia dan antioksidan dari zat fitokimia yang dikandungnya. Penelitian mengenai pemberian 100-400 mg/ekor/hari jus biji pepaya selama 14 hari terbukti menurunkan 23-55\% kolesterol LDL tikus Sprague Dawley hiperlipidemia. ${ }^{6}$ Penelitian lain menunjukkan pemberian 100-400 mg/ekor/oral/hari ekstrak biji pepaya selama 30 hari dapat meningkatkan kolesterol HDL dan menekan kolesterol non HDL tikus wistar jantan. ${ }^{7}$
Komponen utama jus biji pepaya yang memiliki efek hipolipidemia adalah flavonoid, saponin dan tanin. Flavonoid berperan dalam menghambat penyerapan kolesterol, meningkatkan ekskresi empedu dan ekspresi reseptor LDL. ${ }^{8}$ Sedangkan saponin mendukung efek hipolipidemia melalui peningkatan ekskresi asam empedu dan penurunan aktivitas 3-hydroxi-3-methylglutaryl coenzyme A (HMG-CoA) reductase yang menghambat sintesis kolesterol. $^{9}$ Tanin juga berperan dalam penurunan aktivitas HMG-CoA reductase dan Acyl CoA-cholesterol-oacyltransferase (ACAT), serta mereduksi stres oksidatif makrofag. ${ }^{10}$

Pemilihan tikus sebagai sampel penelitian dikarenakan tikus tidak dapat muntah, memiliki kemiripan fisiologis dengan manusia dibandingkan dengan hewan lain dan lebih mudah dikontrol dari asupan makanan dan aktivitas fisik sehingga memperkecil terjadinya bias saat penelitian. ${ }^{11}$ Penelitian sebelumnya membuktikan jus biji pepaya mampu memperbaiki kolesterol LDL secara bermakna pada diet terkontrol. Keefektifan jus biji pepaya pada diet tidak terkontrol (diet tinggi kolesterol) masih belum diketahui. Berdasarkan latar belakang tersebut, maka peneliti ingin mengkaji pengaruh pemberian jus biji pepaya terhadap rasio kolesterol LDL:HDL tikus Sprague Dawley dislipidemia dengan diet tidak terkontrol.

\section{METODE PENELITIAN}

Penelitian yang dilakukan di Laboratorium Fisiologi Hewan Fakultas Matematika dan Ilmu Pengetahuan Alam Universitas Negeri Semarang (UNNES) ini merupakan penelitian experimental laboratorik jenis randomized control groups prepost design. ${ }^{12}$ Variabel bebas pada penelitian ini adalah pemberian jus biji pepaya (Carica pepaya L.) sedangkan variabel terikat dalam penelitian ini adalah rasio kolesterol LDL:HDL.

Sampel penelitian yang digunakan adalah tikus jantan galur Sprague Dawley umur 8 minggu dengan berat badan rata-rata 150-180 gram yang diperoleh dari Unit Pengembangan Hewan Percobaan (UPHP) Universitas Gadjah Mada, Yogyakarta. Besar sampel minimal dalam penelitian ini ditentukan berdasarkan rumus Federer $(\mathrm{t}-1)(\mathrm{n}-1) \geq 15, \mathrm{t}$ merupakan jumlah kelompok perlakuan sedangkan $n$ merupakan besar 
sampel setiap kelompok perlakuan sehingga didapatkan hasil 6 ekor. $^{12}$ Penelitian ini menggunakan 7 ekor tikus untuk setiap kelompok perlakuan sehingga jumlah tikus yang digunakan adalah 28 ekor. Pada saat perlakuan, terjadi drop out pada masing-masing kelompok sehingga jumlah sampel menjadi 24 ekor.

Seluruh sampel diadaptasi terlebih dahulu selama 7 hari dengan menggunakan pakan standar BR-2 sebanyak 20 gram/ekor/hari dan minum ad libithum. Selanjutnya, sampel dibagi menjadi 4 kelompok dengan simple random sampling yaitu kelompok kontrol negatif, kelompok kontrol positif, kelompok perlakuan dosis $400 \mathrm{mg}$ dan kelompok perlakuan dosis $800 \mathrm{mg}$. Kelompok kontrol negatif diberikan pakan standar sampai akhir penelitian, kelompok kontrol positif dan kelompok perlakuan diberi pakan standar serta pakan tinggi kolesterol selama 30 hari untuk membuat tikus menjadi dislipidemia. Sebelum memasuki tahap intervensi dilakukan pengambilan darah awal. Pada tahap intervensi, pakan standar dan tinggi kolesterol tetap dilanjutkan pada kelompok kontrol positif dan ditambahkan jus biji pepaya $400 \mathrm{mg}$ dan $800 \mathrm{mg}$ pada kelompok perlakuan dosis $400 \mathrm{mg}$ dan $800 \mathrm{mg}$.

Pakan tinggi kolesterol berupa kuning telur puyuh mentah diblender dan diberikan melalui sonde sebanyak $10 \%$ dari pakan standar atau 2 ml/ekor/hari. ${ }^{13}$ Pemilihan kuning telur puyuh sebagai pakan tinggi kolesterol dikarenakan kandungan kolesterol kuning telur puyuh lebih tinggi dibanding bahan makanan lain yaitu sebanyak $2.139,17 \mathrm{mg} / 100 \mathrm{gram}$ bahan makanan. ${ }^{14}$

Jus biji pepaya yang diberikan berasal dari biji pepaya (Carica papaya L.) varietas Bangkok dengan tingkat kematangan $80 \%$ yang dihaluskan menggunakan blender, kemudian ditimbang sebanyak $400 \mathrm{mg}$. Setelah itu ditambahkan air hingga $1 \mathrm{ml}$ lalu disaring dan diberikan melalui sonde. Air yang dibutuhkan dalam pembuatan jus biji pepaya pada dosis $400 \mathrm{mg}$ adalah $580 \mathrm{mg}$, sehingga perbandingan biji pepaya dan air ialah 40:58. Jus biji pepaya pada dosis $800 \mathrm{mg}$ berasal dari $2 \mathrm{ml}$ jus biji pepaya dosis $400 \mathrm{mg}$ yang telah dibuat.

Dosis jus biji pepaya yang diberikan berasal dari dosis efektif jus biji pepaya dalam menurunkan kolesterol LDL yang setara dengan efek penurunan lovastatin berdasarkan penelitian sebelumnya yaitu sebesar $400 \mathrm{mg} /$ ekor/hari. ${ }^{6}$ Dosis $400 \mathrm{mg} / \mathrm{ekor} / \mathrm{hari}$ dan $800 \mathrm{mg} / \mathrm{ekor} / \mathrm{hari}$ dipilih sebagai dosis penelitian ini untuk menganalisis efek dosis efektif dan dua kali dosis efektif terhadap rasio kolesterol LDL:HDL. Dosis tersebut merupakan dosis aman penggunaan jus biji pepaya yaitu $<2000 \mathrm{mg} / \mathrm{ekor} /$ hari. $^{7}$

Pengambilan darah sampel sebelum intervensi dimaksudkan untuk melihat rasio kolesterol LDL:HDL setelah pemberian pakan tinggi kolesterol selama 30 hari. Sedangkan rasio kolesterol LDL:HDL akhir didapat setelah pemberian jus biji pepaya selama 30 hari. Sampel darah diambil sebanyak $2 \mathrm{ml}$ melalui pleksus retroorbitalis menggunakan mikrohematokrit, kemudian di sentrifuge untuk mendapatkan serumnya. ${ }^{11}$ Rasio kolesterol LDL:HDL didapat dari perbandingan kadar kolesterol LDL dengan kolesterol HDL dimana kolesterol LDL ditentukan menggunakan reagen diasis dan kolesterol HDL ditentukan dengan metode CHOD-PAP. ${ }^{4}$

Data yang diperoleh diolah dengan program komputer. Data tersebut diuji normalitasnya dengan uji Saphiro Wilk. Perubahan rasio kolesterol LDL:HDL sebelum dan setelah perlakuan menggunakan uji statistik parametrik Paired t-test. Perbedaan pengaruh dosis dari keempat kelompok perlakuan terhadap rasio kolesterol LDL:HDL dianalisis menggunakan uji statistik parametrik One Way Anova dan uji lanjut LSD (Least Significant Difference). ${ }^{15}$ 


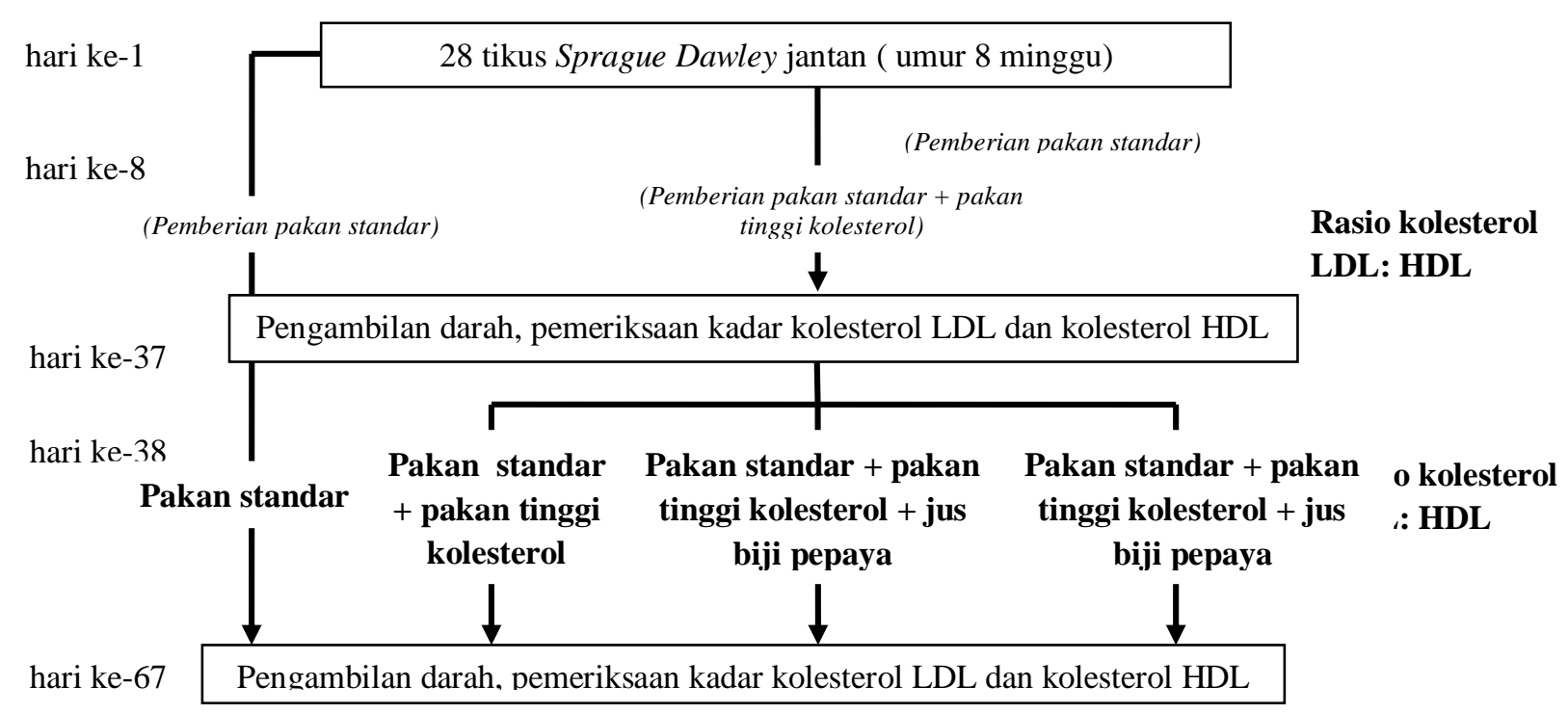

\section{Gambar 1. Alur Penelitian}

\section{HASIL PENELITIAN}

\section{Karakteristik Sampel}

Sampel pada penelitian ini adalah 28 ekor tikus Sprague Dawley jantan dislipidemia usia 8 minggu dengan berat badan berkisar antara 150180 gram. Sampel dipelihara dalam kandang individu dengan suhu ruangan berkisar antara 28$32^{\circ} \mathrm{C}$ dan siklus pencahayaan 12 jam. Kandang dibersihkan setiap hari dan pemeliharaan dilakukan oleh peneliti. Pada saat perlakuan, terjadi drop out pada masing-masing kelompok sehingga jumlah sampel menjadi 24 ekor.

\section{Kandungan zat fitokimia biji pepaya}

Kandungan zat fitokimia dalam 100 gram biji pepaya dalam bentuk utuh dan jus ditampilkan pada tabel 1 .

Tabel 1. Kandungan zat fitokimia dalam 100 gram biji pepaya

\begin{tabular}{lll}
\hline & Jus biji pepaya $(\mathbf{m g})$ & Biji pepaya $(\mathbf{m g})$ \\
\hline Flavonoid & 646,1 & 947,7 \\
\hline Saponin & 69,3 & 88,39 \\
\hline Tanin & 140,9 & 189,35 \\
\hline Antosianin & 0 & 0 \\
\hline Antroquinon & 0 & 0 \\
\hline
\end{tabular}

Analisis fitokimia secara kualitatif dan kuantitatif pada tabel 1 dilakukan di Laboratorium kimia Universitas Muhammadiyah Malang, Jawa Timur. Analisis dilakukan pada biji pepaya dan jus biji pepaya. Hasil analisis fitokimia menujukkan bahwa kandungan fitokimia secara kuantitas pada biji pepaya dan jus biji pepaya berbeda. Kandungan fitokimia pada bentuk jus lebih rendah dikarenakan adanya proses penyaringan yang menyebabkan zat fitokimia ikut terbuang pada bagian yang disaring. Penelitian ini menggunakan biji pepaya dalam bentuk jus karena pengolahan dengan jus merupakan metode yang efisien dan efektif serta aplikatif dalam kehidupan sehari-hari sehingga dapat meningkatkan nilai guna biji pepaya. Selain itu, dari aspek daya terima, bentuk jus lebih dipilih untuk dikonsumsi dibanding biji pepaya utuh karena biji pepaya tanpa dihancurkan memiliki struktur yang keras.

\section{Berat Badan dan Asupan Pakan Sampel}

Tabel 2 menampilkan perbedaan berat badan awal dan akhir penelitian untuk melihat keterkaitan antara perubahan berat badan dengan asupan pakan sampel dan rasio kolesterol LDL:HDL. 
Tabel 2. Hasil Analisis Bivariat Rerata Berat Badan

\begin{tabular}{|c|c|c|c|c|c|c|}
\hline \multirow[b]{2}{*}{ Kelompok } & \multirow[b]{2}{*}{$\mathbf{N}$} & \multicolumn{2}{|c|}{ Rerata \pm SD (unit) } & \multirow[b]{2}{*}{$\Delta$} & \multirow[b]{2}{*}{$\begin{array}{l}\Delta \\
\%\end{array}$} & \multirow[b]{2}{*}{$p$} \\
\hline & & $\begin{array}{l}\text { Sebelum } \\
\text { Perlakuan }\end{array}$ & $\begin{array}{l}\text { Setelah } \\
\text { Perlakuan }\end{array}$ & & & \\
\hline $\mathrm{K}-$ & 6 & $207.9 \pm 22.9^{\mathrm{a}}$ & $262.8 \pm 30.7^{\mathrm{a}}$ & $54.8 \pm 14.3$ & 26.36 & $0.000^{\mathrm{b}} *$ \\
\hline $\mathrm{K}+$ & 6 & $203.7 \pm 11.8^{\mathrm{a}}$ & $263.8 \pm 22.5^{\mathrm{a}}$ & $60.1 \pm 27.2$ & 29.50 & $0.003^{\mathrm{b}} *$ \\
\hline $\mathrm{Pa}$ & 6 & $219.8 \pm 23.5^{\mathrm{a}}$ & $283.0 \pm 17.4^{\mathrm{a}}$ & $63.2 \pm 8.48$ & 28.75 & $0.000^{\mathrm{b} *}$ \\
\hline $\mathrm{Pb}$ & 6 & $211.9 \pm 9.66^{\mathrm{a}}$ & $277.9 \pm 19.8^{\mathrm{a}}$ & $66.0 \pm 13.5$ & 31.15 & $0.000^{\mathrm{b} *}$ \\
\hline
\end{tabular}

${ }^{\mathrm{a}}$ One Way Anova ${ }^{\mathrm{b}}$ Paired $t$-test ${ }^{*}$ berbeda bermakna $(p<0,05)$

Keterangan : K- : kelompok kontrol negatif

$\mathrm{K}+$ :kelompok kontrol positif

$\mathrm{Pa}$ : kelompok perlakuan dosis $400 \mathrm{mg}$

$\mathrm{Pb}$ : kelompok perlakuan dosis $800 \mathrm{mg}$

Tabel 2 menunjukkan rerata berat badan sampel sebelum dan selama perlakuan. Sebelum perlakuan, rerata berat badan antar kelompok memiliki perbedaan yang tidak bermakna $(p=0,478)$, begitu pula setelah perlakuan

$(p=0,355)$. Delta rerata berat badan antar kelompok juga menunjukkan perbedaan yang tidak bermakna $(p=0,717)$. Hasil analisis uji paired $t$ test menunjukkan adanya peningkatan berat badan seluruh kelompok secara bermakna $(p<0,05)$.

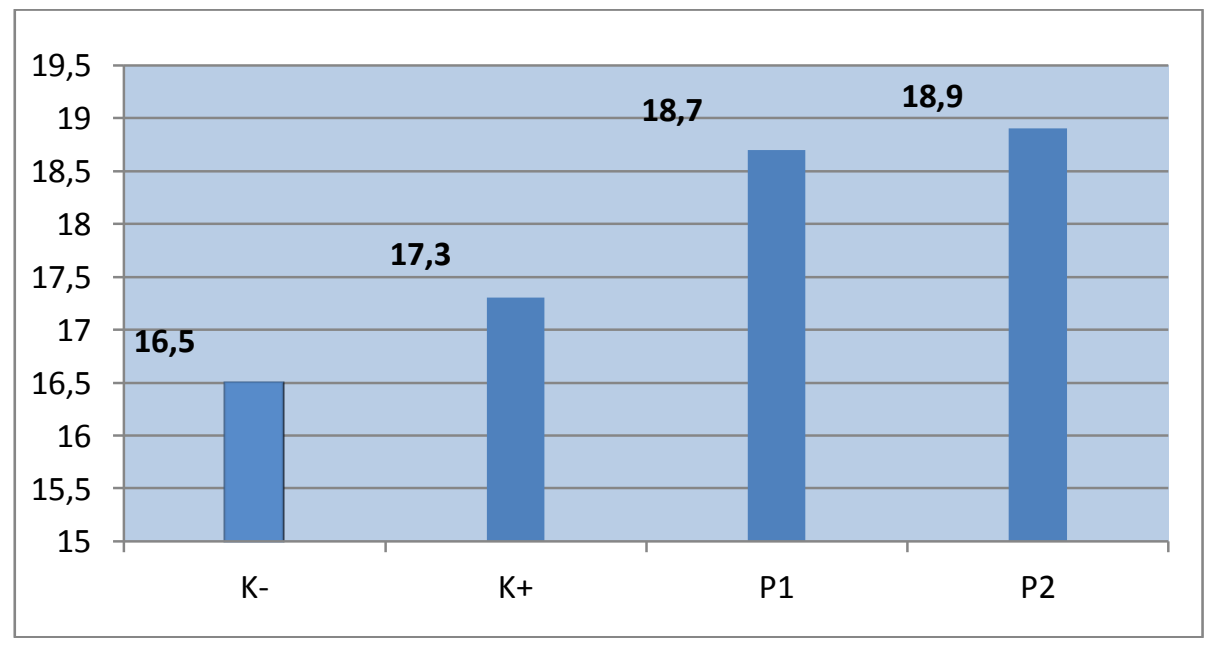

Gambar 2. Diagram asupan pakan pada masing-masing kelompok

Gambar 2 menunjukkan bahwa rerata asupan pakan sampel paling tinggi adalah kelompok perlakuan dosis $800 \mathrm{mg}$ yaitu 18,9 gram/hari, sedangkan yang paling rendah adalah kelompok kontrol negatif yaitu 16,5 gram/hari. Dapat disimpulkan bahwa faktor yang memicu peningkatan berat badan sampel adalah besarnya asupan pakan.

\section{Perubahan Rasio Kolesterol LDL:HDL}

Sebelum intervensi, sampel mengalami masa aklimatisasi atau masa adaptasi, kemudian diinduksi dislipidemia. Setelah dilakukan pengambilan darah awal atau setelah pemberian pakan tinggi kolesterol, dilanjutkan dengan perlakuan yaitu pemberian jus biji pepaya dengan dosis yang berbeda selama 30 hari. Tabel 3 menampilkan pengaruh rasio kolesterol LDL:HDL sebelum dan setelah perlakuan yang diuji dengan paired $t$-test. 
Tabel 3. Rerata rasio kolesterol LDL:HDL sebelum dan setelah pemberian jus biji pepaya selama 30 hari

\begin{tabular}{|c|c|c|c|c|c|c|}
\hline \multirow[b]{2}{*}{ Kelompok } & \multirow[b]{2}{*}{$\mathbf{N}$} & \multicolumn{2}{|c|}{ Rerata \pm SD (unit) } & \multirow[t]{2}{*}{$\Delta$} & \multirow{2}{*}{$\begin{array}{l}\Delta \\
\%\end{array}$} & \multirow[b]{2}{*}{$\boldsymbol{P}$} \\
\hline & & $\begin{array}{l}\text { Sebelum } \\
\text { Perlakuan }\end{array}$ & $\begin{array}{l}\text { Setelah } \\
\text { Perlakuan }\end{array}$ & & & \\
\hline$\overline{\mathrm{K}-}$ & 6 & $1.98 \pm 0.57$ & $2.04 \pm 0.55$ & $0.06 \pm 0.77$ & 0.03 & 0,898 \\
\hline $\mathrm{K}+$ & 6 & $2.95 \pm 0.82$ & $3.20 \pm 0.69$ & $0.26 \pm 0.96$ & 8.84 & 0,546 \\
\hline $\mathrm{Pa}$ & 6 & $2.64 \pm 0.70$ & $2.25 \pm 0.54$ & $\begin{array}{l}- \\
0.39 \pm 0.99\end{array}$ & -14.77 & 0,376 \\
\hline $\mathrm{Pb}$ & 6 & $2.94 \pm 1.01$ & $2.11 \pm 0.65$ & $0.82 \pm 1.29$ & -27.98 & 0,180 \\
\hline
\end{tabular}

\section{Paired t test}

Tabel 3 menunjukkan bahwa rasio kolesterol LDL:HDL sebelum dan setelah pemberian pakan tinggi kolesterol selama 30 hari (sebelum perlakuan) mengalami peningkatan. Peningkatan tersebut terjadi pada kelompok kontrol positif, kelompok perlakuan jus biji pepaya 400mg dan $800 \mathrm{mg}$.

Hasil analisis menunjukkan terdapat perbedaan perubahan rasio kolesterol LDL:HDL antara kelompok tanpa jus biji pepaya dengan kelompok yang diberi jus biji pepaya. Kelompok tanpa jus biji pepaya (kelompok kontrol negatif dan kontrol positif) mengalami peningkatan rasio kolesterol LDL:HDL masing-masing 0,03\% dan
$8.84 \%$, namun secara statistik tidak bermakna. Kelompok dengan jus biji pepaya (kelompok perlakuan dosis $400 \mathrm{mg}$ dan $800 \mathrm{mg}$ ) mengalami penurunan rasio kolesterol LDL:HDL, walaupun secara statistik tidak bermakna. Penurunan paling tinggi terjadi pada kelompok perlakuan dosis 800 mg yaitu sebesar 0,82 atau sekitar 27,98\%.

Rasio Kolesterol LDL:HDL sebelum dan setelah perlakuan

Gambaran perbedaan rasio kolesterol LDL:HDL sebelum dan setelah perlakuan antar kelompok diuji dengan One Way Anova ditampilkan pada tabel 4 dan dilanjutkan dengan uji $L S D$ yang ditampilkan pada tabel 5 .

Tabel 4. Rasio Kolesterol LDL:HDL antar kelompok perlakuan

\begin{tabular}{|c|c|c|c|c|c|c|}
\hline \multirow{2}{*}{ Variabel } & & \multicolumn{4}{|c|}{ Rerata \pm SD (unit) } & \multirow[b]{2}{*}{$p$} \\
\hline & & $K-(n=6)$ & $K+(n=6)$ & $\operatorname{Pa}(n=6)$ & $\mathrm{Pb}(\mathrm{n}=6)$ & \\
\hline $\begin{array}{l}\text { Rasio } \\
\text { LDL:HDL } \\
\text { (unit) }\end{array}$ & $\begin{array}{r}\text { kolesterol } \\
\text { sebelum }\end{array}$ & $\begin{array}{l}1.98 \pm 0.5 \\
7\end{array}$ & $\begin{array}{l}2.95 \pm 0.8 \\
2\end{array}$ & $\begin{array}{l}2.64 \pm 0.7 \\
0\end{array}$ & $\begin{array}{l}2.94 \pm 1.0 \\
1\end{array}$ & 0.156 \\
\hline $\begin{array}{l}\text { Rasio } \\
\text { LDL:HDL } \\
\text { (unit) }\end{array}$ & $\begin{array}{r}\text { kolesterol } \\
\text { setelah }\end{array}$ & $\begin{array}{l}0.95 \pm 0.3 \\
9\end{array}$ & $\begin{array}{l}1.32 \pm 0.2 \\
6\end{array}$ & $0.8 \pm 0.11$ & $1.0 \pm 0.35$ & $\begin{array}{l}0.014 \\
*\end{array}$ \\
\hline
\end{tabular}

Tabel 5. Hasil analisis perubahan rasio kolesterol LDL:HDL setelah perlakuan

\begin{tabular}{lll}
\hline Uji Post-hoc & Perbedaan rerata & P \\
\hline K- vs K+ & 1.16 & $0.004^{*}$ \\
K- vs $\mathrm{Pa}$ & 0.21 & 0.569 \\
$\mathrm{~K}-$ vs $\mathrm{Pb}$ & 0.07 & 0.849 \\
$\mathrm{~K}+$ vs $\mathrm{Pa}$ & 0.95 & $0.015^{*}$ \\
$\mathrm{~K}+$ vs $\mathrm{Pb}$ & 1.09 & $0.006^{*}$ \\
$\mathrm{~Pa}$ vs $\mathrm{Pb}$ & 0.14 & 0.703 \\
\hline
\end{tabular}

Uji LSD *berbeda bermakna

Tabel 4 menunjukkan bahwa sebelum perlakuan, rasio kolesterol LDL:HDL antar kelompok tidak terdapat perbedaan yang bermakna $(p=0,156)$. Setelah perlakuan, rasio kolesterol LDL:HDL antar kelompok memiliki perbedaan bermakna $(p=0,014)$. Uji lanjutan pada tabel 5 
menunjukkan terdapat perbedaan yang bermakna antara kelompok kontrol positif dengan kelompok kontrol negatif $(p=0,004)$, kelompok perlakuan jus biji papaya $400 \mathrm{mg}(p=0,015)$ dan kelompok perlakuan $800 \mathrm{mg}(p=0,006)$.

\section{Analisis Perbedaan Perubahan Rasio Kolesterol LDL:HDL}

Gambaran delta rasio kolesterol LDL:HDL sebelum dan setelah perlakuan dianalisis menggunakan One Way Anova ditampilkan pada tabel 6

Tabel 6. Hasil Analisis Perbedaan Perubahan Rasio Kolesterol LDL:HDL

\begin{tabular}{llll}
\hline \multirow{2}{*}{ Kelompok } & $\mathbf{n}$ & $\begin{array}{l}\text { Delta Rasio } \\
\text { LDL:HDL }\end{array}$ & $\boldsymbol{p}$ \\
\cline { 3 - 4 } & & Rerata \pm SD (unit) & \\
$\mathrm{K}-$ & 6 & $0.06 \pm 0.77$ & 0.337 \\
$\mathrm{~K}+$ & 6 & $0.26 \pm 0.96$ & \\
$\mathrm{~Pa}$ & 6 & $-0.39 \pm 0.99$ & \\
$\mathrm{~Pb}$ & 6 & $-0.82 \pm 1.29$ & \\
\hline
\end{tabular}

Tabel 6 menunjukkan perbedaan perubahan rasio kolesterol LDL:HDL dari sebelum hingga setelah perlakuan. Hasil uji beda rerata antar kelompok menunjukkan perbedaan rasio kolesterol LDL:HDL antar kelompok perlakuan tidak bermakna secara statistik $(p=0,337)$. Namun secara deskriptif perubahan rasio kolesterol LDL:HDL tertinggi terdapat pada kelompok perlakuan $800 \mathrm{mg}$.

\section{PEMBAHASAN}

\section{Kandungan zat jus biji pepaya}

Analisis zat fitokimia secara kualitatif dan kuantitatif pada biji pepaya dilakukan di Laboratorium kimia Universitas Muhammadiyah Malang (UMM), Jawa Timur. Analisis dilakukan pada biji pepaya dan jus biji pepaya. Hal ini dimaksudkan untuk membandingkan kandungan zat fitokimia pada biji pepaya dan jus biji pepaya. Analisis fitokimia pada biji pepaya sudah dilakukan pada penelitian sebelumnya di Afrika tetapi terbatas pada segi kualitatif. Terdapat kesesuaian kandungan zat fitokimia dengan analisis pada penelitian sebelumnya yang menunjukkan bahwa biji pepaya mengandung flavonoid, saponin dan tanin. Penelitian sebelumnya juga menunjukkan biji pepaya mengandung antosianin dan antroquinon, akan tetapi analisis secara kualitatif dan kuantitatif pada penelitian ini tidak ditemukan kandungan tersebut.

Hasil analisis fitokimia pada tabel 1 memperlihatkan adanya perbedaan kadar fitokimia biji pepaya dengan jus biji pepaya. Kandungan flavonoid dalam biji pepaya sebanyak $947,7 \mathrm{mg}$ sedangkan pada jus biji pepaya sebanyak 646,1 mg, kandungan saponin dalam biji pepaya sebanyak $88,39 \mathrm{mg}$ sedangkan pada jus biji pepaya sebanyak 69,3 mg, dan kandungan tanin dalam biji pepaya sebanyak $189,35 \mathrm{mg}$ sedangkan pada jus biji pepaya sebanyak $140,9 \mathrm{mg}$. Dari segi kualitatif, kandungan zat fitokimia pada biji pepaya dan jus biji pepaya adalah sama, akan tetapi secara kuantitas, biji pepaya mengandung zat fitokimia yang lebih tinggi dibanding biji pepaya dalam bentuk jus. Perbedaan jumlah kandungan ini dikarenakan adanya proses penyaringan pada bentuk jus sehingga jumlah zat fitokimia yang dihasilkan lebih rendah.

\section{Berat badan subjek}

Penimbangan berat badan tikus dan sisa pakan dilakukan setiap hari. Dari hasil pengukuran berat badan menunjukkan bahwa terdapat perbedaan berat badan sebelum dan selama perlakuan antar kelompok yang tidak bermakna. Berat badan sebelum dan setelah perlakuan mengalami peningkatan yang secara statistik bermakna. Peningkatan berat badan yang paling tinggi terdapat pada kelompok perlakuan dosis 800 mg yaitu sebesar $31,15 \%$ sedangkan peningkatan berat badan yang paling rendah terdapat pada kelompok kontrol negatif yaitu sebesar 26,36\%. Hal tersebut terjadi karena kelompok kontrol negatif hanya mendapat pakan standar dengan jumlah yang sama dengan seluruh sampel yaitu sebesar 20 gram/hari, sedangkan kelompok kontrol positif, kelompok perlakuan dosis $400 \mathrm{mg}$ dan 800 mg mendapat pakan standar dan penambahan pakan tinggi kolesterol hingga akhir penelitian. Terdapat kesesuaian dengan hasil penelitian sebelumnya bahwa pemberian kuning telur puyuh 
sebanyak 2 gram/hari selama 4 minggu dapat meningkatkan berat badan sampel. ${ }^{13}$

Peningkatan berat badan paling tinggi pada kelompok perlakuan dosis $800 \mathrm{mg}$ juga dipengaruhi oleh besarnya asupan pakan pada kelompok tersebut dibanding kelompok perlakuan selain kontrol negatif yaitu sebesar 18,9 gram/hari dimana pakan standar mengandung protein sebesar $15 \%$ dan lemak sebesar 3-7\%. Hal ini yang menyebabkan kelompok perlakuan dosis $800 \mathrm{mg}$ memiliki berat badan lebih besar dibanding kelompok yang lain. Diagram asupan pakan (Gambar 2) menunjukkan bahwa semakin besar asupan pakan sampel maka peningkatan berat badan juga semakin tinggi.

\section{Pemberian Pakan Tinggi Kolesterol}

Keadaan dislipidemia tikus pada penelitian ini diinduksi menggunakan pakan tinggi kolesterol berupa kuning telur puyuh mentah sebesar 2 $\mathrm{ml} /$ ekor/hari yang mengandung kolesterol 42,7834 mg. Pemilihan kuning telur puyuh ini dikarenakan telur tersebut mengandung kolesterol lebih tinggi dibandingkan dengan bahan makanan lain yaitu 2.139,17 mg/100 gram sehingga diharapkan mampu meningkatkan rasio kolesterol LDL:HDL. ${ }^{14}$ Keadaan dislipidemia diketahui dengan cara membandingkan rasio kolesterol LDL:HDL tikus yang mendapat pakan tinggi kolesterol (kelompok kontrol positif, kelompok perlakuan dosis $400 \mathrm{mg}$ dan $800 \mathrm{mg}$ ) dengan kelompok kontrol negatif yang mendapat pakan standar. Rasio kolesterol LDL:HDL kelompok kontrol negatif (1.98 \pm 0.57$)$ digunakan sebagai gambaran rasio kolesterol LDL:HDL tikus normal.

Hasil analisis beda rerata menunjukkan bahwa sebelum perlakuan atau setelah pemberian pakan tinggi kolesterol tidak terdapat perbedaan rasio kolesterol LDL:HDL yang bermakna antar kelompok. Namun secara deskriptif, kelompok kontrol negatif memiliki rasio kolesterol LDL:HDL paling rendah dibandingkan dengan kelompok lain. Hal ini dikarenakan kelompok kontrol negatif hanya mendapat pakan standar, tanpa penambahan kuning telur puyuh mentah. Selain itu, jika dilihat dari asupan pakan dan berat badan, kelompok tersebut memiliki rerata asupan dan berat badan yang lebih rendah dibandingkan dengan kelompok lain.

Kelompok kontrol positif memiliki rasio kolesterol LDL:HDL tertinggi, diikuti dengan kelompok perlakuan dosis $800 \mathrm{mg}$ dan $400 \mathrm{mg}$ masing-masing $48,5 \%, 47,9 \%$ dan $33,3 \%$. Faktor yang mempengaruhi tingginya rasio kolesterol LDL:HDL pada ketiga kelompok tersebut yaitu adanya penambahan pakan tinggi kolesterol selama 30 hari. Terdapat kesesuaian dengan penelitian sebelumnya dimana pemberian kuning telur puyuh selama 4 minggu pada tikus dapat meningkatkan kolesterol LDL sebesar $68 \%$ dan menurunkan kolesterol HDL sebesar 14,5\% secara bermakna. ${ }^{14}$

Konsumsi lemak jenuh dan kolesterol dapat meningkatkan kadar LDL dengan menurunkan sintesis dan aktivitas reseptor LDL, menekan ekskresi asam empedu, dan meningkatkan pembentukan VLDL dengan ukuran lebih kecil yang mengandung kolesterol relatif lebih banyak serta digunakan oleh jaringan ekstrahepatik lebih lambat yang cenderung bersifat aterogenik. Keadaan ini dapat berpengaruh terhadap peningkatan rasio kolesterol LDL:HDL. ${ }^{16,17}$

Tingginya rasio pada ketiga kelompok tersebut juga didukung oleh asupan pakan dan berat badan, kelompok tersebut memiliki rerata asupan dan berat badan yang lebih tinggi dibandingkan dengan kelompok kontrol negatif. Berbagai penelitian menunjukan bahwa sampel dengan presentase lemak tinggi cenderung memiliki kolesterol total, kolesterol LDL, trigliserida lebih tinggi dan kolesterol HDL lebih rendah dibandingkan dengan sampel berat badan normal. Trigliserida berlebih akan disimpan dibawah kulit dan menjadi sumber utama pembentukan VLDL dan LDL di hati dan akan disekresi ke dalam cairan darah. Hal tersebut juga berpengaruh terhadap peningkatan rasio kolesterol LDL:HDL. ${ }^{16}$

\section{Pengaruh Jus Biji Pepaya terhadap Rasio Kolesterol LDL:HDL}

Jus biji pepaya diharapkan mampu menurunkan rasio kolesterol LDL:HDL. Pada penelitian ini, rerata rasio kolesterol LDL:HDL setelah perlakuan menunjukkan adanya perbedaan yang bermakna antar kelompok $(p=0,014)$. Pada tabel 3 yang menampilkan rerata rasio kolesterol LDL:HDL sebelum dan setelah pemberian jus biji pepaya menunjukkan bahwa pada kelompok perlakuan dosis $400 \mathrm{mg}$ dan $800 \mathrm{mg}$ mengalami penurunan secara berturut-turut dari 2,64 menjadi 2,25 atau turun sebesar $14,77 \%$ dan dari 2.93 menjadi 2,11 atau turun sebesar $27.98 \%$, akan tetapi penurunan tersebut secara statistik tidak bermakna yaitu $(p=0,376)$ dan $(p=0,180)$.

Penurunan rasio kolesterol LDL:HDL pada kelompok perlakuan dosis $400 \mathrm{mg}$ dan $800 \mathrm{mg}$ disebabkan adanya zat fitokimia berupa flavonoid, saponin, dan tanin dalam biji pepaya dimana 100 gram jus biji pepaya mengandung 646,1 mg 
flavonoid, 69,3 $\mathrm{mg}$ saponin, dan 140,9 $\mathrm{mg}$ tanin. Flavonoid merupakan molekul polifenolik dengan atom karbon 15 bersifat larut air. Flavonoid terdiri dari chalcone, flavon, flavonol, flavanon, antosianin, isoflavonoids dan lain-lain. ${ }^{18}$ Mekanisme penurunan rasio kolesterol LDL:HDL oleh flavonoid melalui beberapa faktor yaitu penghambatan absorbsi kolesterol dan peningkatan ekskresi empedu. Flavonoid dapat bertindak sebagai kofaktor enzim kolesterol esterase dan penghambat absorbsi kolesterol makanan melalui penghambatan pembentukan misel sehingga kolesterol mengendap dan penyerapannya dapat ditekan. Peghambatan pembentukan misel sebagai lemak yang dicerna dan diabsorbsi menyebabkan penurunan kadar kolesterol darah. ${ }^{8,17}$

Flavonoid juga dapat mengaktifkan sistem multi enzim, seperti sitokrom P-450 dan b5 yang mempengaruhi metabolisme lipid dan asam empedu. Enzim sitokrom P-450 memiliki kemampuan memediasi pembentukan asam empedu dari kolesterol melalui beberapa enzim sehingga terjadi peningkatkan jumlah asam empedu. Peningkatan tersebut dapat meningkatkan ekskresi asam empedu sebagai jalur utama eliminasi kolesterol. Flavonoid juga berperan dalam menekan kosentrasi trigliserida dengan mengaktifasi sintesis cAMP. AMP mengaktifkan protein kinase, enzim tersebut meningkatkan hidrolisa trigliserida sehingga menurunkan trigliserida dalam darah dan hati. Selain itu, flavonoid juga mengaktifasi reseptor LDL (apo B100, E). Peningkatan reseptor LDL mengindikasikan terjadinya penurunan kolesterol LDL. ${ }^{8,19}$

Selain flavonoid, jus biji pepaya memiliki kandungan saponin yang memiliki mekanisme hipolipidemia melalui penurunan sintesis kolesterol dengan menghambat aktivitas HMGCOA reductase dan peningkatkan ekskresi asam empedu akibat meningkatnya konversi kolesterol menjadi asam empedu. Saponin juga mampu mengubah absorbsi kolesterol dan asam empedu dengan menginterupsi formasi misel, sehingga kolesterol tidak dapat diabsorbsi. Disisi lain, saponin berperan dalam meningkatkan pergantian atau pengelupasan sel usus melalui tindakan membranolytic sehingga meningkatkan hilangnya kolesterol di membran sel ke dalam sel yang terkelupas. ${ }^{9,17}$

Mekanisme hipolipidemia jus biji papaya juga didukung oleh zat fitokimia tanin. Tanin dapat menghambat enzim HMG-COA reductase yang berperan mensintesis kolesterol dan enzim ACAT yang bertanggung jawab dalam esterifikasi kolesterol. Terhambatnya aktivitas HMG-COA reductase akan menurunkan sintesis kolesterol di hati sehingga menurunkan sintesis Apo B-100 dan meningkatkan reseptor LDL pada permukaan hati. Dengan demikian, kolesterol LDL darah akan ditarik ke hati sehingga menurunkan kolesterol LDL dan VLDL. Hasil penelitian eksperimental pada tikus hiperkolesterolemia menunjukkan bahwa suplementasi tanin dapat menurunkan $71 \%$ aktivitas HMG-COA reductase kolesterol dan 23\% kolesterol LDL serta meningkatkan kolesterol HDL secara bermakna. ${ }^{10}$

Tanin juga dapat menghambat aktivitas enzim ACAT untuk esterifikasi kolesterol sehingga menekan penggabungan kolesterol ester membentuk kilomikron dan meningkatkan ketersediaan kolesterol bebas untuk transpor kolesterol terbalik sehingga mencegah akumulasi lipid di makrofag. Selain itu juga menurunkan formasi lipoprotein dengan menekan jumlah kolesterol ester untuk sintetis VLDL di hati. ${ }^{10,20}$

\section{KETERBATASAN PENELITIAN}

Keterbatasan penelitian ini adalah tidak dilakukan pengujian jenis flavonoid yang terdapat dalam jus biji pepaya sehingga tidak dapat diketahui jenis spesifik flavonoid yang berperan dalam perubahan rasio kolesterol LDL:HDL, serta pengujian kandungan serat dalam biji pepaya.

\section{SIMPULAN}

Pemberian jus biji pepaya selama 30 hari pada dosis $400 \mathrm{mg} / \mathrm{ekor} / \mathrm{hari}$ dan $800 \mathrm{mg} / \mathrm{ekor} / \mathrm{hari}$ mampu menurunkan rasio kolesterol LDL:HDL masing-masing sebesar $14,77 \%$ dan $27.98 \%$ pada tikus Sprague Dawley dislipidemia dengan diet kolesterol 42,7834 mg/hari, tetapi tidak bermakna. Tidak terdapat perbedaan efektifitas antara kedua dosis tersebut.

\section{SARAN}

Perlu dilakukan penelitian lanjut menggunakan subjek hewan coba mengenai efek pemberian suspensi jus biji pepaya terhadap rasio kolesterol LDL:HDL.

\section{UCAPAN TERIMA KASIH}

Puji syukur kepada Allah SWT, terima kasih kepada pembimbing dan para reviewer yang telah membimbing penelitian ini hingga dapat terlaksana sampai akhir. Penulis juga mengucapkan terima kasih kepada laboran Laboratorium Fisiologi Hewan UNNES dan 
Laboratorium Kimia UMM yang telah membantu pelaksanaan penelitian ini serta orang tua dan teman-teman atas dukungan yang telah diberikan.

\section{DAFTAR PUSTAKA}

1. Mendis S, Puska P, Norrving B, editors. Global Atlas on Cardiovascular Disease Prevention and Control. World Health Organization. Geneva. 2011.

2. Soepardi J. Gambaran Penyakit Tidak Menular di Rumah Sakit di Indonesia Tahun 2009 dan 2010. Pusat Data dan Informasi Kementrian Kesehatan RI. 2012.

3. Ballanntyne CM, O'Keefe, Gotto AM. Dyslipidemia and Atherosclerosis Essentials Fourth Edition. Massachussetts: Jones and Bartlett Publishers; 2009. 5-6.

4. Fernandez ML, Webb D. The LDL to HDL Cholesterol Ratio as a Valuable Tool to Evaluate Coronary Heart Disease Risk. Journal of the American College of Nutrition 2008; 27 (1): 1-5.

5. Anonymous. Executive Summary of the Third Report of the National Cholesterol Education Program (NCEP) Expert Panel on Detection, Evaluation, and Treatment of High Blood Cholesterol in Adults (Adult Treatment Panel III). JAMA. 2002; 5215: 113-41.

6. Nuraini M, Orbaniyah S. Pengaruh Pemberian Jus Biji Pepaya (Carica papaya Linn) terhadap Penurunan Kadar Low Density Lipoproteins (LDL) Plasma Tikus Sprague Dawley. Program Sarjana Kedokteran dan Ilmu Kesehatan Universitas Muhammadiyah Yogyakarta. 2011.

7. Adeneye AA, Olagunju JA. Preliminary hypoglycemic and hypolipidemic activities of the aqueous seed extract of Carica papaya Linn in Wistar rats. Biology and Medicine 2009; 1 (1): 1-10.

8. Olivera T, Ricardo KFS, Almeida MR, Costa MR, Nagem TJ. Hypolipidemic Effect of Flavonoids and Cholestyramine in Rats Tania. Latin American Journal of Pharmacy 2007; 26 (3): 407-10.

9. Afrose S, Hossain S, Salma U, Miah AG, Tsujii H. Dietary Karaya Saponin and Rhodobacter Capsulatus Exert Hypocholesterolemic Effects by Suppression of Hepatic Cholesterol Synthesis and Promotion of Bile Acid Synthesis in Laying Hens. Science and Technology Shinshu University Japan. 2010; 1-7.

10. Do GM, Kwon EY, Tae YH, Kim HJ, Jeon SM, Lee $\mathrm{MK}$, et al. Tannic acid is more effective than clofibrate for the elevation of hepatic $\beta$-oxidation and the inhibition of 3-hydroxy-3-methyl-glutarylCoA reductase and aortic lesion formation in apo Edeficient mice. British Journal of Nutrition 2011: 19.

11. Sharp PE, Regina MCL. The Laboratory Rat. USA: CRC Press LLC; 1998.

12. Notoatmojo S. Metodologi Penelitian Kesehatan. Jakarta: Penerbit PT Rineka Cipta; 2010.
13. Astirani AE, Muwarni H. Pengaruh Pemberian SARI Daun Cincau (Premna oblongifolia Merr) terhadap Kadar Kolesterol HDL dan Kolesterol LDL Tikus Sprague Dawley Dislipidemia. Semarang: Universitas Diponegoro; 2012.

14. Bambang D. Efek kolesterolemik berbagai telur. Media gizi dan keluarga 2003, 27(2): 58-65.

15. Dahlan MS. Statistik untuk Kedokteran dan Kesehata. Jakarta: Salemba Medika; 2011.

16. Botham KM, Mayes PA. Sintesis, Transpor dan Ekresi Kolesterol. Dalam: Murray RK, Daryl KG, Peter AM, Victor WR. Biokimia Harper 27th ed. Jakarta: Penerbit Buku Kedokteran EGC; 2009.p.239-48

17. Gropper SS, Smith JL, Groff JL. Advanced Nutrition and Human Metabolism Fifth Edition. USA : Wadsworth, Cengage Learning. 2009; 131-75.

18. Njoku V, Obi C. Phytochemical Constituents of Some Selected Medicinal Plants. African Journal of Pure and Applied Chemistry 2009; 3 (11): 228-233.

19. Rusell DW. Fifty years of advances in bile acid synthesis and metabolism. Journal of Lipid Research 2009; 50: 120-5.

20. Meuwese MC, Franssen R, Stroes ESG, Kastelein JJP. And Then There Were Acyl Coenzyme A : Cholesterol Acyl Transferase Inhibitors. Current Opinion in Lipidology 2006; 17: 426-30. 